New policy

\section{raises fears}

\section{of meddling}

\section{Washington}

For the second time in as many months, the Reagan Administration is being accused of injecting politics into the selection of scientists for independent advisory panels. According to an official at the Food and Drug Administration (FDA), appointment authority over its scientific advisory panels is gradually being taken away from the FDA commissioner and given to the Department of Health and Human Services (HHS). What worries FDA officials is that HHS recently suggested at least two scientists whom FDA believes are unqualified and who were proposed for political reasons.

Earlier this year, the Department of Agriculture admitted that it had been running security checks and "political" checks on scientists nominated for peerreview panels to evaluate proposals for its competitive grants programme but the political checks have since been dropped.

The troubles at FDA, however, seem more serious. Although the secretary of HHS has always had authority to appoint the advisory panels at FDA, that function has traditionally been delegated to FDA itself. One FDA official said that although HHS has given general directions on the numerical balance of the committees; approval by HHS was generally a formality.

Over the past several months, however, HHS has rewritten the panels' charters as they come up for renewal, retracting FDA's delegated control over them. Although FDA is still being asked to identify possible candidates it is also, for the first time, being told to furnish a list of alternatives. And the final decisions are apparently now being made in the office of HHS secretary Richard S. Schweiker.

Of even greater concern to FDA is that the secretary's office has begun to offer suggestions of its own. According to a report in the Washington Post last week, which was confirmed by FDA, these suggestions included a woman psychiatrist who was a founder of the "California ProLife Council," an anti-abortion group. She was suggested by HHS as the consumer representative on a panel that evaluates contraceptive and abortion drugs. FDA told the secretary's office that she was unqualified, but whether FDA's opinion will be considered is still uncertain.

The Washington Post also reported that HHS suggested a California physician whose main qualification, according to

FDA scientists, was apparently that he listed Dr Loyal Davis - Nancy Reagan's stepfather - as a reference.

The Department of Health and Human Services claims that it is doing nothing improper. An HHS official said the department is merely continuing the centralization of appointment authority begun under President Carter. The official also denied that the secretary's office was making its own recommendations for committee positions, and said it was simply passing on to FDA all names that it receives from congressmen and senators of both parties.

That interpretation was contradicted by an FDA official, who said that while names had occasionally been passed on before, what was happening now was quite different. The official said that HHS was coming back with new names after FDA had submitted its list of candidates, and was specifically asking if these new names were qualified for specific positions. $\mathrm{Mr}$ Garret Cuneo, the HHS official now apparently in charge of the selection process, refused to comment on the matter.

The effects of the new appointment policy remain to be seen; no obviously political appointments have been made so far. But even if political manipulation does not occur, FDA is worried that the new

\title{
NIH urged to act on germ war
}

\section{Washington}

In response to rumour that the US Army and Navy are seeking to develop "defensive biological weapons systems" using recombinant DNA techniques, two American biomedical scientists have called on the National Institutes of Health (NIH) specifically to prohibit such work.

Dr Richard Goldstein of Harvard Medical School and Dr Richard Novick of the Public Health Research Institute of New York City are proposing an amendment to the NIH recombinant DNA guidelines to ban "the construction of biological weapons by molecular cloning"'. The proposal will be considered at the next meeting of the Recombinant DNA Advisory Committee on 28 June.

According to $\mathrm{Dr}$ Goldstein, several scientists have recently been approached by the military about the possibility of using cloning techniques to produce biological warfare agents. The United States signed the 1982 Biological Weapons Convention, agreeing "never in any circumstances to develop, produce [or] stockpile" biological agents for other than peaceful purposes. But Dr Goldstein says the military apparently interprets this as not covering the development in the laboratory of suitable organisms for "defensive" - by which is meant deterrent - purposes.

In a statement describing their proposed procedures will make putting together an advisory panel even harder. The aim in the past has been to get not only leading scientists in a range of specialities, but also to have different geographical regions and women and minorities represented on each panel. FDA officials wonder how these goals can still be met when it is cut out of the process and when it is limited to saying whether the HHS candidates are qualified or not.

Meanwhile, at the Department of Agriculture, the dust seems to have settled. According to the office of Agriculture Secretary John R. Block, the decision to run political checks on scientists nominated for peer-review panels was really the result of a misunderstanding. Political checks are normally run on policy advisers; last autumn, the Office of Management and Budget ordered the department to bring the peer-review panels under the same federal act that governs policy panels. Agriculture department of ficials then assumed that political checks would have to be run for them as well.

After disclosure of the political checks on scientists, Block ordered them to be stopped. The scientists who had not yet been cleared by Block's office were then all approved at once. Block's office maintains, however, that none of the information

amendment, the scientists argue that "the use of molecular cloning for the deliberate construction of biological weapons is, per $s e$, the most serious biohazard imaginable for this technology", and that "it constitutes an egregious misuse of scientific knowledge",

Although the NIH guidelines strictly apply only to researchers working under NIH grants, the Defense Department has so far agreed to follow them. But the amendment's sponsors say that even if their proposed ban is not binding on military research, it would "provide automatic public support for a refusal of the scientific community to participate in the development of biological weapons and it may convince governments that the 1982 prohibition should be construed as applying to laboratory research".

Under the recent relaxation of the DNA guidelines (see Nature 29 April, p.793), the previous ban on cloning of toxin genes and on release of recombinant organisms into the environment was lifted, although permission from NIH is required before proceeding with either. The amendment would restore the ban in these two areas when the aim is construction of biological warfare agents, and extend it to previously unregulated activities such as the cloning of viruses for this purpose.

Stephen Budiansky 
obtained in the political checks was used.

The department will continue to run nominees' names through an FBI security check which it calls "routine", although neither the National Institutes of Health nor the National Science Foundation follows this practice.

Professor Joe Key of the University of Georgia, a director of the competitive grants programme under President Carter, wonders if the checks were an attempt to cause trouble for the four-year-old programme, which is still small and fragile and viewed with some suspicion elsewhere in the department. The bulk of agricultural research (some $\$ 1,500$ million a year, of which $\$ 15$ million is for competitive grants) is funded through land-grant colleges and state experimental stations, which receive government funds according to an automatic allocation formula. This latest incident did little to help the competitive programme's vulnerable position.

Stephen Budiansky

\section{West German environmentalists Greens' delight \\ Heidelberg}

The Hamburg elections on 6 June have left the environmentalist "green" party in a powerful position. While the conservative Christian Democratic Union (CDU) won one more seat in the Hamburg Senate than the Social Democrats (SPD), the greens (Grün-Alternativ-Liste) won nine seats and now hold the balance of power.

In Hamburg, CDU leader Walther Leisler Kiet is now trying to form a nonparty "citizens' senate"'. If he fails, Mayor Klaus von Dohnanyi of SPD will have to ask the greens for their support. The greens have set their faces against coalition and have said that they will cooperate only on strict conditions, including Hamburg's abandonment of nuclear power.

The aftershocks of the Hamburg election continue to reverberate in all political strata in West Germany. The personal intervention of Chancellor Helmut Schmidt and Foreign Minister Hans Dietrich Genscher failed to turn the tide in favour of the Social Democrats, while the Free Democrats, the lesser partner with the Social Democrats in the Bonn coalition, again failed narrowly to reach the 5 per cent threshold necessary to qualify for a seat.

The polarized vote in Hamburg reflects the shakiness of the Bonn coalition as well as the strength of the green-left. If the Social Democrats lose only one more Land, the Christian Democrats will have a clear two-thirds majority in the Bundesrat and could block all government legislation. Rumours are now rife that the Free Democrats will leave the coalition after the Hesse election on 26 September, perhaps joining with the Christian Democrats. The deepening green intrusion into West German politics is at least partly responsible.
With seats in five parliaments, the greens have become the third strongest party. The abrasive challenge they offer to the assumptions of the established social industrial system is proving hard for even the Social Democrats to meet. They are concerned that "integrating" green issues would further alienate the traditional working class base without necessarily keeping ecologically-minded young voters. Indeed, there are wide differences between the Social Democrats and the greens except on individual issues such as the RhineDanube canal or the protection of wildlife.

The central goals of the greens are the realization, by means of a social welfare state, of the recommendations of Global 2000 and of disarmament. They call, for example, for radical change to a no-growth society, the use of alternative technologies and energy sources, conservation, economy and peace. They oppose the "compromise politics" of the Social Democrats.

Voters are mainly young and well educated and the focus is often local: cauliflower cancers of eels from the polluted Elbe and the discovery of tonnes of nerve gas in a ramshackle chemical factory near the city centre were important at Hamburg. The parties are autonomous at every level, so that there are no declared leaders and the small new national party controls neither the policies nor the attitudes towards coalition of the Länder parties. To ensure the five per cent vote, the Länder-Grünen have often joined with other groups, some of whom have made uncomfortable allies.

Their anarchic demands for Rousseauesque self-determination, their use of violence and frequent threats to make West Germany ungovernable if minority demands are not met raise spectres of the Weimar Republic.

In September, the Hessen greens will go it alone, campaigning especially against the extension of Frankfurt Airport and plans for four local reprocessing plants for atomic waste. They expect a 10 per cent vote, a Christian Democrat parliament and a defeat for the Social/Free Democrat alliance that would indeed have national repercussions.

Sarah Tooze

\section{European science policy}

\section{Give and take}

\section{Brussels}

The second report on European science policy by Crest, the Committee on Scientific and Technical Research, tells the familiar story of how, after 15 years of trying to bridge the technology gap with the United States, Europe still lags behind in the latest technologies. Of the million or more European scientists - representing 20 per cent of the world's total $-350,000$ are researchers, and science in Europe cost $\$ 35,000$ million in 1980 . The new report, which has still to be published, goes beyond its predecessor in comparing the national research and development policies of the ten EEC member states.

Energy research, which since 1974 has been a priority, accounted for a smaller share of the research and development budget at 11 per cent in 1980 than in either the United States (12 per cent) or Japan ( 25 per cent). Nuclear (fission) research has seen its importance slump, particularly in West Germany and France.

Allocations to industry research grew by 15 per cent a year in the Community as a whole between 1978 and 1980 but are thought to have returned to pre-1974 levels only last year. The increase has been marked in Italy and the United Kingdom, but UK spending is still below the 1974 level.

Space research, where international cooperation is at its most developed in Europe, shows France and West Germany sharing more than two-thirds of the spending, worth $\$ 860$ million in 1980 . Curiously Italy and Belgium, recent years have contributed the greatest proportion of their budgets to space research.

Agricultural research turns out to play the biggest role in the smaller member states. In Ireland and Greece a quarter of public research and development money goes on agriculture, which is equivalent to only 3.7 per cent of the EEC's total spending. Agriculture is also important in Denmark and the Netherlands which spent $\$ 3.7$ and $\$ 6.8$ per head respectively compared with an EEC average of \$2.7, and \$3.1 in the United Kingdom. Italy's outlay seems small at $\$ 0.9$ per inhabitant, considering agriculture's social and economic importance in the country.

International cooperation is still important but its share of public budgets has fallen by as much as 25 per cent since 1978. Between 1974 and 1978 it was constant at 10 per cent but now there are wide differences among the member states. Britain's contribution, for example, has increased by 25 per cent since 1970 .

The ten members of the EEC also differ in the response of their companies to the technological challenge. The role of the state in industrial research is greatest in the United Kingdom ( 30 per cent), France (22 per cent) and West Germany (20 per cent), but less than 10 per cent in the rest. Measuring research in companies as the proportion of expenditure on research and development to the value added of the manufacturing puts British companies first. The proportion of research expenditure is 4.7 per cent followed by West German companies (3.9 per cent), French companies ( 3.5 per cent) and Dutch companies ( 3.3 per cent); in the United States though, the average is 5.7 per cent. But if a distinction between public expenditure and companies' own funds is made, the picture changes. US companies spend the most ( 3.8 per cent) followed by the Japanese ( 3.4 per cent).

The report argues that many of the 